Invited review

\title{
Cross-talk between calcium and reactive oxygen species signaling
}

\author{
Yuan YAN, Chao-liang WEI, Wan-rui ZHANG, He-ping CHENG, Jie LIU1 \\ Laboratory of Calcium Signaling, Institute of Molecular Medicine, Peking University, Beijing 100871, China
}

\section{Key words}

calcium; reactive oxygen species; signal transduction; receptor cross talk

${ }^{1}$ Correspondence to Dr Jie LIU.

Phn 86-10-6275-4605.

Fax 86-10-6276-5957.

E-mail jliu@pku.edu.cn

Received 2006-04-15

Accepted 2006-05-21

doi: $10.1111 /$ j.1745-7254.2006.00390.x

\begin{abstract}
Calcium $\left(\mathrm{Ca}^{2+}\right)$ and reactive oxygen species (ROS) constitute the most important intracellular signaling molecules participating in the regulation and integration of diverse cellular functions. Here we briefly review cross-talk between the two prominent signaling systems that finely tune the homeostasis and integrate functionality of $\mathrm{Ca}^{2+}$ and ROS in different types of cells. $\mathrm{Ca}^{2+}$ modulates ROS homeostasis by regulating ROS generation and annihilation mechanisms in both the mitochondria and the cytosol. Reciprocal redox regulation of $\mathrm{Ca}^{2+}$ homeostasis occurs in different physiological and pathological processes, by modulating components of the $\mathrm{Ca}^{2+}$ signaling toolkit and altering characteristics of local and global $\mathrm{Ca}^{2+}$ signals. Functionally, interactions between $\mathrm{Ca}^{2+}$ and ROS signaling systems can be both stimulatory and inhibitory, depending on the type of target proteins, the ROS species, the dose, duration of exposure, and the cell contexts. Such extensive and complex cross-talk might enhance signaling coordination and integration, whereas abnormalities in either system might propagate into the other system and undermine the stability of both systems.
\end{abstract}

\section{Introduction}

The calcium $\left(\mathrm{Ca}^{2+}\right)$ ion, as a ubiquitous intracellular messenger, regulates many different cellular functions, including contraction, secretion, metabolism, gene expression, cell survival and cell death ${ }^{[1]}$. Likewise, reactive oxygen species (ROS) such as superoxide anion $\left(\mathrm{O}_{\dot{2}}^{-}\right)$and hydrogen peroxide $\left(\mathrm{H}_{2} \mathrm{O}_{2}\right)$ are widely involved in physiological and pathophysiological processes through oxidizing proteins, lipids and polynucleotides ${ }^{[2,3]}$. Recent studies have underscored the notion that the $\mathrm{Ca}^{2+}$ and ROS signaling systems are intimately integrated such that $\mathrm{Ca}^{2+}$-dependent regulation of components of ROS homeostasis might influence intracellular redox balance, and vice versa. On one hand, a number of ROS-generating and antioxidant systems of living cells have been shown to be $\mathrm{Ca}^{2+}$-dependent ${ }^{[4,5]}$. Conversely, regulation of $\mathrm{Ca}^{2+}$ signals can be redox-dependent. The incredible versatile $\mathrm{Ca}^{2+}$ signals, depending on an extensive $\mathrm{Ca}^{2+}$ signaling toolkit, can act in various contexts of space, time and amplitude ${ }^{[1,6]}$. Redox modulation of components of the $\mathrm{Ca}^{2+}$ signaling toolkit occurs in different physiological and pathological processes, resulting in altered amplitude and spatiotemporal characteristics of $\mathrm{Ca}^{2+}$ signals.
In this brief review, we discuss the specific mechanisms underlying the interaction and integration of these two powerful intracellular signaling systems in different types of cells.

\section{$\mathrm{Ca}^{2+}$ modulation of ROS homeostasis}

ROS play an important role in physiological cellular functions by activating several enzymatic cascades and transcription factors ${ }^{[7]}$. Excessive ROS signals, however, are detrimental, causing $\mathrm{Ca}^{2+}$ overload, mitochondrial depolarization, cytochrome $\mathrm{c}$ release, lipid peroxidation, transcription factor activation and DNA damage, and lead to apoptotic and non-apoptotic cell death. As such, oxidative stress is increasingly recognized as a causative factor in the development of a diverse array of diseases, including neurodegenerative diseases, malignant diseases, diabetes mellitus, atherosclerosis, and ischemia/reperfusion injury ${ }^{[7]}$. The intracellular redox state reflects the dynamic balance between ROS production and the antioxidant capacity of the cell. Increasing evidence indicates that intracellular $\mathrm{Ca}^{2+}$ modulates both ROS generation and ROS clearance processes and thereby shifts the redox state toward either a more oxidized or reduced direction in a context-sensitive manner. 
$\mathrm{Ca}^{2+}$-induced ROS production There are many intracellular ROS generation sites (Figure 1). Of them, the electron transport chain resides on the mitochondria and there are plenty of extramitochondrial enzymes in the plasma membrane or in the cytosol, such as cell-surface NADPH-oxidase, peroxisomes, cytochrome $\mathrm{P} 450$, xanthine oxidase, cyclooxygenase, and lipooxygenase ${ }^{[8,9]}$. Mitochondria provide the main source of physiological ROS production, with $1 \%-2 \%$ of total electrons flowing through the respiratory chain leaking to produce $\operatorname{ROS}^{[10]}$. The primal ROS made by electron transport chains is $\mathrm{O}_{\dot{i}}^{-}$, which is changed to $\mathrm{H}_{2} \mathrm{O}_{2}$ either by spontaneous dismutation or catalyzed by superoxide dismutase (SOD). One important function of mitochondrial $\mathrm{Ca}^{2+}$ is to stimulate the tricarboxylic acid (TCA) cycle ${ }^{[11]}$ and oxidative phosphorylation ${ }^{[12-15]}$. Specifically, 3 dehydrogenases of the TCA cycle (pyruvate dehydrogenase, isocitrate dehydrogenase and oxoglutarate dehydrogenase $)^{[11]}$, the ATP synthase (complex $\mathrm{V})^{[14]}$, and the adenine nucleotide translocase ${ }^{[12]}$ are all activated by $\mathrm{Ca}^{2+}$. Hence, $\mathrm{Ca}^{2+}$ might increase ROS generation by enhancing metabolism. During this process, more electrons leak from the respiratory chain while more $\mathrm{O}_{2}$ is consumed to produce ATP. To this end, previous studies have shown a positive correlation between mitochondrial ROS generation and the basal metabolic rate ${ }^{[16,17]}$. Interestingly, $\mathrm{Ca}^{2+}$ can also enhance $\mathrm{ROS}$ produc- tion when complexes of the electron transport chain are inhibited. As shown by in vitro experiments, $\mathrm{Ca}^{2+}$ stimulates ROS production in isolated rat heart mitochondria in the presence of antimycin A (complex III inhibitor ${ }^{[18]}$. Similar observations have been made with rotenone (complex I inhibitor) treatment of brain mitochondria ${ }^{[19]}$. This phenomenon appears to be tissue-specific, because addition of $\mathrm{Ca}^{2+}$ to brain mitochondria in the presence of antimycin A does not stimulate ROS generation ${ }^{[19]}$.

The underlying mechanism for $\mathrm{Ca}^{2+}$-induced mitochondrial ROS generation is not fully understood. Cadenas and Boveris proposed that mitochondria depolarization is responsible for the $\mathrm{Ca}^{2+}$ effects ${ }^{[18]}$, whereas others have attributed the $\mathrm{Ca}^{2+}$ effects to the alteration of mitochondrial membrane structure $^{[19]}$. Studies on isolated mitochondria ${ }^{[4,20-22]}$ have demonstrated that high concentration of mitochondrial $\mathrm{Ca}^{2+}$ $\left(\left[\mathrm{Ca}^{2+}\right]_{\mathrm{m}}\right)$ triggers mitochondrial permeability transition pore (mPTP) opening and enhances ROS production, but the cascade of events linking mPTP opening to ROS generation remains elusive. The $\mathrm{Ca}^{2+}$-induced $\mathrm{mPTP}$ opening can be inhibited by antioxidants such as MCI-186 $6^{[23]}$ or catalase ${ }^{[24]}$. Furthermore, nearly 100 different proteins are lost from the mitochondrial inner membrane, including cytochrome c, glutathione (GSH) and other matrix solutes during mPTP opening. In principle, any of these molecules could enhance ROS

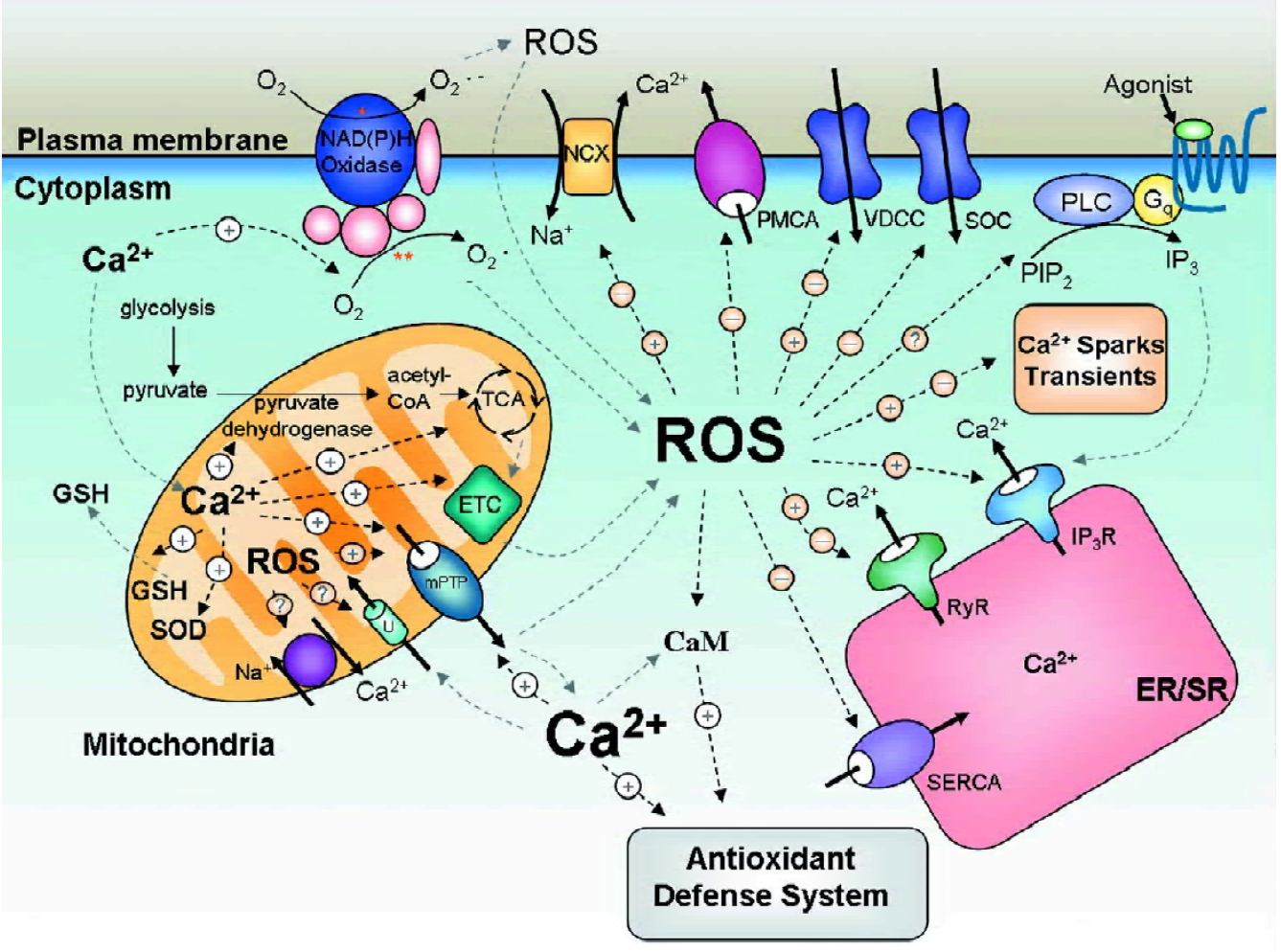

Figure 1. Cross-talk between $\mathrm{Ca}^{2+}$ and ROS signaling. $\mathrm{Ca}^{2+}$ modulates ROS generation and annihilation systems in the mitochondria and the cytosol. Meanwhile, components of $\mathrm{Ca}^{2+}$ signaling toolkit are regulated by ROS, so as to alter local and global $\mathrm{Ca}^{2+}$ signals in physiological and pathological processes. SOC, store-operated $\mathrm{Ca}^{2+}$ channel; PLC: phospholipase C; PIP2, phosphatidylinositol-4,5bisphosphate; TCA, tricarboxylic acid; ETC, electron transport chain; $\mathrm{U}$, uniporter. 
generation.

In addition to the regulation of mitochondrial ROS production, $\mathrm{Ca}^{2+}$ regulates multiple extramitochondrial ROSgenerating enzymes both in physiological and pathological processes. Cell-surface NADPH oxidases, with rapid kinetics of activation and inactivation, are the most important multienzyme complexes in the generation of ROS involved in receptor-mediated signaling cascades ${ }^{[8]}$. The best studied among them is the phagocyte NADPH-oxidase, which consists of a dimer of transmembrane subunits, gp9 ${ }^{\text {phox }}$ and $\mathrm{p} 22^{\text {phox }}$, and three cytosolic subunits, $\mathrm{p} 67^{\text {phox }}, \mathrm{p} 47^{\text {phox }}$, and rac2. An additional component, $\mathrm{p} 40^{\text {phox }}$, is also associated with oxidase, but its functional role is unclear ${ }^{[25]}$. Activity of neutrophil oxidases, including NADPH-oxidase, is $\mathrm{Ca}^{2+}$-dependent $^{[26]}$. Buffering intracellular or extracellular $\mathrm{Ca}^{2+}$ decreases generation of oxygen metabolites in human neutrophils ${ }^{[27]}$. $\mathrm{NAD}(\mathrm{P}) \mathrm{H}$ oxidase and its homologs are present in a variety of nonphagocytic cells including smooth muscle cells, chondrocytes, kidney epithelial cells, endothelial cells, prostate cancer cells ${ }^{[21]}$, and spermatocytes ${ }^{[28]}$. In response to elevations of the cytosolic $\mathrm{Ca}^{2+}$ concentration $\left(\left[\mathrm{Ca}^{2+}\right]_{\mathrm{c}}\right)$, NADPH oxidase 5 (NOX5), a homolog of the gp91 ${ }^{\text {phox }}$ subunit of the phagocyte NADPH oxidase, generates large amounts of superoxide ${ }^{[28]}$, which attributes to conformation change of NOX5 induced by $\mathrm{Ca}^{2+[29]}$. It has been shown ${ }^{[30,31]}$ that activities of other ROS-generating enzymes are regulated by $\left[\mathrm{Ca}^{2+}\right]_{\mathrm{c}}$ directly or indirectly.

$\mathrm{Ca}^{2+}$ regulation of antioxidant defense system To counteract the damaging potential of ROS, cells use the antioxidant defense system, which involves both enzymatic and nonenzymatic oxidant defense mechanisms. $\mathrm{Ca}^{2+}$ can directly activate antioxidant enzymes, such as plant catalase and GSH reductase, increase the level of SOD in animal cells ${ }^{[5]}$, and induce mitochondrial GSHrelease early in $\mathrm{Ca}^{2+}$-induced mPTP opening $^{[4]}$. Alternatively, calmodulin $(\mathrm{CaM})$, a ubiquitous $\mathrm{Ca}^{2+}$-binding protein, interacts with antioxidant enzymes involved in ROS homeostasis. CaM binds to and activates some plant catalases in the presence of $\mathrm{Ca}^{2+}$, and downregulates $\mathrm{H}_{2} \mathrm{O}_{2}$ levels ${ }^{[32]}$. Collectively, these studies indicate that $\mathrm{Ca}^{2+}$ plays dual roles in regulating ROS homeostasis. The net $\mathrm{Ca}^{2+}$ effects on ROS generation and annihilation appear to be tissue-specific and context-sensitive, and, within a given cell, are differentially regulated in local subcellular compartments.

\section{ROS regulation of $\mathrm{Ca}^{2+}$ signaling}

The $\mathrm{Ca}^{2+}$ signaling system comprises hundreds and up to thousands of protein players that are involved in virtually every aspect of cell biology and physiology. Any influence on the $\mathrm{Ca}^{2+}$ signaling toolkit might change the spatiotemporal profile of local and global $\mathrm{Ca}^{2+}$ signals, contributing to the efficiency, specificity and complexity of $\mathrm{Ca}^{2+}$ signal transduction. In this section we briefly discuss how ROS modify key $\mathrm{Ca}^{2+}$ signaling proteins and reshape local and global $\mathrm{Ca}^{2+}$ signal amplitudes and kinetics (Figure 1).

Voltage-dependent $\mathrm{Ca}^{2+}$ channels $\mathrm{Ca}^{2+}$ entry into excitable cells through voltage-dependent $\mathrm{Ca}^{2+}$ channels (VDCCs) is essential for membrane electrical activity and intracellular signal transduction. Many studies have focused on ROS modulation of VDCC activity. $\mathrm{H}_{2} \mathrm{O}_{2}$ has been shown to accelerate the overall channel opening process in neuronal $\mathrm{P} / \mathrm{Q}$-type $\mathrm{Ca}^{2+}$ channels expressed in Xenopus oocytes ${ }^{[8]}$. Studies in whole-cell-clamped guinea pig ventricular myocytes have shown that exogenous ROS suppresses Ltype $\mathrm{Ca}^{2+}$ current ${ }^{[33]}$. Similarly, sulphydryl-oxidating agents, 2,2-dithiodipyridine and thimerosal, also inhibit the activity of rabbit smooth muscle L-type $\mathrm{Ca}^{2+}$ channels expressed in $\mathrm{CHO}$ cells ${ }^{[34]}$, and it was found that free $\mathrm{SH}$ groups of L-type $\mathrm{Ca}^{2+}$ channels are essential for ROS modulation. Although the effects of $\mathrm{H}_{2} \mathrm{O}_{2}$ and other ROS on single DHPR channel activity have not been reported; previous studies indicate a ROS-induced decrease in this current of skeletal muscle ${ }^{[31]}$. In contrast, it has also been reported that $\mathrm{H}_{2} \mathrm{O}_{2}$ exerts no significant effect on L-type $\mathrm{Ca}^{2+}$ current in pancreatic $\beta$ cells $^{[35]}$. In Arabidopsis guard cells, Pei and colleagues ${ }^{[36]}$ identified a hyperpolarization-dependent $\mathrm{Ca}^{2+}$-permeable cation channel that is activated by $\mathrm{H}_{2} \mathrm{O}_{2}$.

Intracellular $\mathrm{Ca}^{2+}$ release channels The release of $\mathrm{Ca}^{2+}$ from the endo/sarcoplasmic reticulum (ER/SR) mediated by ryanodine receptors (RyR) and 1,4,5-inositol-triphosphate receptors $\left(\mathrm{IP}_{3} \mathrm{R}\right)$ is a primary $\mathrm{Ca}^{2+}$ signaling event. An RyR or $\mathrm{IP}_{3} \mathrm{R}$ channel is a homotetramer with each subunit containing many free cysteine residues that are susceptible to redox reaction by ROS. For instance, each of the four homologous $560 \mathrm{kDa} \mathrm{RyR}_{1}$ proteins contains approximately 50 free cysteine residues $^{[37]}$, and approximately 21 free cysteines per subunit of $\mathrm{RyR}_{2}{ }^{[38]}$. Changes in the redox state of RyR and $\mathrm{IP}_{3} \mathrm{R}$ would affect their activities. There are three types of RyR expressed in mammalian cells, known as $\mathrm{RyR}_{1}, \mathrm{RyR}_{2}$, and $\mathrm{RyR}_{3} . \mathrm{RyR}_{1}$ is the dominant isoform in skeletal muscle, $\mathrm{RyR}_{2}$ is found in high levels in cardiac muscle, and $\mathrm{RyR}_{3}$ is expressed at relatively low levels in many tissues including diaphragm and brain ${ }^{[39]}$. $\mathrm{RyR}_{1}$ channels, in vitro, were markedly activated by $100 \mu \mathrm{mol} / \mathrm{L}$ and $1 \mathrm{mmol} / \mathrm{L} \mathrm{H}_{2} \mathrm{O}_{2}$ under redox potential clamp conditions ${ }^{[40]}$; were inhibited by $10 \mathrm{mmol} / \mathrm{L}$ $\mathrm{H}_{2} \mathrm{O}_{2}{ }^{[41]}$. Moreover, 3-5 mmol/ $\mathrm{L} \mathrm{H}_{2} \mathrm{O}_{2}$ directly modified the gating of sheep cardiac $\mathrm{RyR}_{2}$, resulting in an increase in chan- 
nel open probability without affecting the conductance ${ }^{[33]}$. Similarly, $\mathrm{H}_{2} \mathrm{O}_{2}$ enhances $\mathrm{Ca}^{2+}$ release from SR in isolated ventricular myocytes. This effect is more prominent in cells previously dialyzed with low concentration thiol reductants, GSH ( $2 \mathrm{mmol} / \mathrm{L}$ ) or dithiothreitol (DTT; $0.5 \mathrm{mmol} / \mathrm{L})^{[42]}$. It is noteworthy that high concentration $\mathrm{GSH}(10 \mathrm{mmol} / \mathrm{L})$ or DTT $(2 \mathrm{mmol} / \mathrm{L})$ itself strongly inhibits $\mathrm{Ca}^{2+}$ release in cardiomyocytes $^{[42]}$. In neurons, activation of RyR $\mathrm{R}_{3}$ by ROS might modify $\mathrm{Ca}^{2+}$-dependent long-term potentiation and long-term depression ${ }^{[37]}$. In the case of $\mathrm{IP}_{3} \mathrm{R}$, it has been reported that $\mathrm{O}_{\dot{2}}^{-}$ enhances $\mathrm{IP}_{3}$-induced $\mathrm{Ca}^{2+}$ release from fractionated vascular smooth muscle $\mathrm{SR}^{[43]}$, and oxidized GSH induces $\mathrm{Ca}^{2+}$ release from $\mathrm{IP}_{3} \mathrm{R}$ in intact hepatocytes ${ }^{[44]}$. Moreover, the data reported by Hu et al ${ }^{[45]}$ demonstrated that exogenous NADPH (substrate of NADPH oxidase) or $\mathrm{H}_{2} \mathrm{O}_{2}$ increases the sensitivity of intracellular $\mathrm{Ca}^{2+}$ stores to $\mathrm{IP}_{3}$ in human endothelial cells. Despite these advances, it remains to be convincingly demonstrated whether endogenous ROS can appropriately modify RyR and $\mathrm{IP}_{3} \mathrm{R}$ activity in intact cells.

$\mathrm{Ca}^{2+}$ pumps and $\mathrm{Na}^{+} / \mathrm{Ca}^{2+}$ exchanger Both the plasma membrane $\mathrm{Ca}^{2+}$-ATPases (PMCA) and the ER/SR Ca ${ }^{2+}$-ATPases (SERCA), as well as $\mathrm{Na}^{+} / \mathrm{Ca}^{2+}$ exchangers (NCX), are sensitive to ROS regulation. ROS can effectively inhibit $\mathrm{Ca}^{2+}$ transport by SERCA in smooth muscle cells ${ }^{[2]}$ and depress cardiac sarcolemmal $\mathrm{Ca}^{2+}$-ATPase ${ }^{[46]}$. SERCA is more sensitive to ROS than PMCA is. For example, $\mathrm{H}_{2} \mathrm{O}_{2}$ and $\mathrm{O}_{\dot{2}}^{-}$can completely uncouple the hydrolytic reaction of PMCA and inhibit the hydrolytic reaction of SERCA ${ }^{[33]}$. Both stimulating and inhibiting regulation of ROS on NCX have been reported in isolated sarcolemmal vesicles and in intact cells. It has been proposed that $\mathrm{H}_{2} \mathrm{O}_{2}$ generated from the xanthine/ xanthine oxidase system $(\mathrm{X} / \mathrm{XO})$ enhances NCX activity in ventricular myocytes, causing $\mathrm{Ca}^{2+}$ overload and triggering arrhythmia during reperfusion, because of the NCX pathological inverted running ${ }^{[47]}$. Similar results were obtained in sarcolemmal vesicles from bovine heart ${ }^{[48,49]}$. In contrast, oxidants from hypoxanthine/xanthine oxidase depress NCX activity in guinea pig ventricular myocytes under voltageclamp conditions ${ }^{[50]}$. The exchanger activity is also inhibited by the oxidizing agent $\mathrm{HOCl}^{[48]}$. Although mitochondrial $\mathrm{NCX}$ and $\mathrm{Ca}^{2+}$ uniporter have been reported to participate in mitochondrial $\mathrm{Ca}^{2+}$ regulation ${ }^{[51]}$, it is not yet clear how they are modulated by intramitochondrial ROS.

Other components of the $\mathrm{Ca}^{2+}$ signaling system that are modulated by ROS include store-operated $\mathrm{Ca}^{2+}$ channel ${ }^{[51]}$, $\mathrm{K}_{\mathrm{Ca}}$ channel ${ }^{[33,52]}$, and $\mathrm{CaM}^{[8]}$. Taken together, ROS as intracellular signaling molecules might directly and indirectly modify components of $\mathrm{Ca}^{2+}$ signaling pathways, thus altering $\mathrm{Ca}^{2+}$ homeostasis and reshaping local and global $\mathrm{Ca}^{2+}$ signals.

Global $\mathrm{Ca}^{2+}$ signaling It has been widely accepted that exogenous ROS could induce dynamic changes in $\left[\mathrm{Ca}^{2+}\right]_{\mathrm{c}}$ in a variety types of cells ${ }^{[54-59]}$. This effect might be due to mobilization of intracellular $\mathrm{Ca}^{2+}$ stores and to influx of extracellular $\mathrm{Ca}^{2+}$. As an important feature of the cross-regulation between ROS and $\mathrm{Ca}^{2+}$, the ROS effect on $\mathrm{Ca}^{2+}$ signaling can vary from stimulative to repressive, depending on the type of oxidants, their concentrations, and duration of exposure. When treated with $100 \mu \mathrm{mol} / \mathrm{L} \mathrm{H}_{2} \mathrm{O}_{2},\left[\mathrm{Ca}^{2+}\right]_{\mathrm{c}}$ of rat cardiomyocytes increased markedly, and continued to rise after washout, whereas $1 \mu \mathrm{mol} / \mathrm{L} \mathrm{H}_{2} \mathrm{O}_{2}$ had no effect on $\left[\mathrm{Ca}^{2+}\right]_{c}{ }^{[58]}$. At an even higher dose, $1 \mathrm{mmol} / \mathrm{L} \mathrm{H}_{2} \mathrm{O}_{2}$ elicits biphasic response in cardiac myocytes, a transient augmentation of $\mathrm{Ca}^{2+}$-induced $\mathrm{Ca}^{2+}$ release followed by a suppression of $\left[\mathrm{Ca}^{2+}\right]_{\mathrm{c}}$ transient after 5 min exposure. The biphasic nature could be explained by a possible ER/SR depletion due to a combination of release enhancement and SERCA inhibition (Figure 1). Conversely, reducing agents such as GSH and DTT attenuate $\left[\mathrm{Ca}^{2+}\right]_{\mathrm{c}}$ transients ${ }^{[3]}$. The effect of ROS on $\mathrm{Ca}^{2+}$ signaling is also tissue specific. For instance, it had been shown that $\mathrm{H}_{2} \mathrm{O}_{2}(100-300 \mu \mathrm{mol} / \mathrm{L})$ activates contraction in skinned skeletal muscle fibers without producing an increase in $\left[\mathrm{Ca}^{2+}\right]_{c}^{[60]}$. Under pathological conditions, such as hypoxia and ischemia/reperfusion injury, mitochondria dysfunction results in ROS increase that mediates the following cytosolic $\mathrm{Ca}^{2+}$ overload ${ }^{[4,59]}$ by triggering $\mathrm{Ca}^{2+}$ release from the ER through $\mathrm{RyR}^{[59]}$ or from the external through $\mathrm{PMCA}^{[4]}$.

Local $\mathrm{Ca}^{2+}$ signaling $\mathrm{Ca}^{2+}$ sparks $^{[61]}$ constitute the elementary $\mathrm{Ca}^{2+}$ releasing events and play an important role in local control of $\mathrm{Ca}^{2+}$ signaling in many types of cells. As is the case with ROS regulation of global $\mathrm{Ca}^{2+}$ signaling, ROS modulation of $\mathrm{Ca}^{2+}$ sparks occurs in a ROS species- and tissue-specific fashion. For example, $\mathrm{O}_{\dot{2}}^{-}$generated from $\mathrm{X} / \mathrm{XO}$ elicits a slowly developing decrease of $\mathrm{Ca}^{2+}$ spark frequency down to $56 \%$ of control in permeabilized rat ventricular myocytes $^{[62]}$. In contrast, mitochondria-derived ROS, generated from diazoxide (an ATP-sensitive $\mathrm{K}^{+}$channel opener)induced mitochondrial depolarization, elevates $\mathrm{Ca}^{2+}$ spark frequency and enhances the coupling of sparks to $\mathrm{Ca}^{2+}$ sensitve $\mathrm{K}^{+}$channels in smooth muscle cells ${ }^{[63]}$. In permeabilized rat skeletal muscle fibers, $50 \mu \mathrm{mol} / \mathrm{L} \mathrm{H}_{2} \mathrm{O}_{2}$ was also found to increase $\mathrm{Ca}^{2+}$ spark frequency ${ }^{[64]}$. More direct evidence is needed to confirm the regulation of local and global $\mathrm{Ca}^{2+}$ signals by mitochondria-derived ROS in physiological and pathological conditions.

\section{Concluding remarks}

Cross-talk between $\mathrm{Ca}^{2+}$ and ROS signaling systems oc- 
curs at multiple levels in different subcellular compartments (eg, the plasma membrane, the cytosol and mitochondria), and involves a constellation of molecular players (Figure 1). The reciprocal interactions between $\mathrm{Ca}^{2+}$ and ROS signaling systems can be both stimulatory and inhibitory, depending on the type of target proteins, the ROS species, the dose, the time history, and the cell contexts. Both ROS generation and clearance as well as $\mathrm{Ca}^{2+}$ signaling are subject to tight local regulation, therefore future study should unravel endogenous high local or compartmentalized ROS (eg, inside the mitochondrial matrix, ER/SR lumen or nucleoplasm) interacting with $\mathrm{Ca}^{2+}$ signaling molecules, and vice versa. Such cross-talk provides not only a fine-tuning mechanism for homeostatic regulation of either system, but also a coupling mechanism for signaling integration in the regulation of physiological functions. Under pathophysiological conditions, however, abnormalities in either signaling system could propagate into the other system, and feedback reinforcement could cause instabilities in both systems. We eagerly await future investigations to enlighten us on the cell logic behind the complex bi-directional interactions of the two signaling systems.

\section{References}

1 Berridge MJ, Lipp P, Bootman MD. The versatility and universality of calcium signalling. Nat Rev Mol Cell Biol 2000; 1: 11-21.

2 Ermak G, Davies KJ. Calcium and oxidative stress: from cell signaling to cell death. Mol Immunol 2002; 38:713-21.

3 Morad M, Suzuki YJ. Redox regulation of cardiac muscle calcium signaling. Antioxid Redox Signal 2000; 2: 65-71.

4 Brookes PS, Yoon Y, Robotham JL, Anders MW, Sheu SS. Calcium, ATP, and ROS: a mitochondrial love-hate triangle. Am J Physiol Cell Physiol 2004; 287: C817-33.

5 Gordeeva AV, Zvyagilskaya RA, Labas YA. Cross-talk between reactive oxygen species and calcium in living cells. Biochemistry-Moscow 2003; 68: 1077-80.

6 Berridge MJ, Bootman MD, Lipp P. Calcium, a life and death signal. Nature 1998; 395: 645-8.

7 Droge W. Free radicals in the physiological control of cell function. Physiol Rev 2002; 82: 47-95.

8 Sauer H, Wartenberg M, Hescheler J. Reactive oxygen species as intracellular messengers during cell growth and differentiation. Cell Physiol Biochem 2001; 11: 173-86.

9 Kevin LG, Novalija E, Stowe DF. Reactive oxygen species as mediators of cardiac injury and protection: the relevance to anesthesia practice. Anesth Analg 2005; 101: 1275-87.

10 Boveris A, Chance B. The mitochondrial generation of hydrogen peroxide. General properties and effect of hyperbaric oxygen. Biochem J 1973; 134: 707-16.

11 McCormack JG, Denton RM. Mitochondrial $\mathrm{Ca}^{2+}$ transport and the role of intramitochondrial $\mathrm{Ca}^{2+}$ in the regulation of energy metabolism. Dev Neurosci 1993; 15:165-73.

12 Mildaziene V, Baniene R, Nauciene Z, Bakker BM, Brown GC,
Westerhoff $\mathrm{HV}$, et al. Calcium indirectly increases the control exerted by the adenine nucleotide translocator over 2-oxoglutarate oxidation in rat heart mitochondria. Arch Biochem Biophys 1995; 324:130-4.

13 Hansford RG, Zorov D. Role of mitochondrial calcium transport in the control of substrate oxidation. Mol Cell Biochem 1998; 184: 359-69.

14 Das AM, Harris DA. Control of mitochondrial ATP synthase in heart cells: inactive to active transitions caused by beating or positive inotropic agents. Cardiovasc Res 1990; 24: 411-7.

15 Balaban RS. Cardiac energy metabolism homeostasis: role of cytosolic calcium. J Mol Cell Cardiol 2002; 34: 1259-71.

$16 \mathrm{Ku} \mathrm{HH}$, Sohal RS. Comparison of mitochondrial pro-oxidant generation and anti-oxidant defenses between rat and pigeon: possible basis of variation in longevity and metabolic potential. Mech Ageing Dev 1993; 72: 67-76.

17 Perez-Campo R, Lopez-Torres M, Cadenas S, Rojas C, Barja G. The rate of free radical production as a determinant of the rate of aging: evidence from the comparative approach. J Comp Physiol 1998; 168: 149-58.

18 Cadenas E, Boveris A. Enhancement of hydrogen peroxide formation by protophores and ionophores in antimycin-supplemented mitochondria. Biochem J 1980; 188: 31-7.

19 Sousa SC, Maciel EN, Vercesi AE, Castilho RF. $\mathrm{Ca}^{2+}$-induced oxidative stress in brain mitochondria treated with the respiratory chain inhibitor rotenone. FEBS Lett 2003; 543: 179-83.

20 Zoratti M, Szabo I. The mitochondrial permeability transition. Biochim Biophys Acta 1995; 1241: 139-76.

21 Vercesi AE, Kowaltowski AJ, Grijalba MT, Meinicke AR, Castilho $\mathrm{RF}$. The role of reactive oxygen species in mitochondrial permeability transition. Biosci Rep 1997; 17: 43-52.

22 Kowaltowski AJ, Naia-da-Silva ES, Castilho RF, Vercesi AE. $\mathrm{Ca}^{2+}$ stimulated mitochondrial reactive oxygen species generation and permeability transition are inhibited by dibucaine or $\mathrm{Mg}^{2+}$. Arch Biochem Biophys 1998; 359: 77-81.

23 Crompton $M$. The mitochondrial permeability transition pore and its role in cell death. Biochem J 1999; 341(Pt 2): 233-49.

24 Castilho RF, Kowaltowski AJ, Meinicke AR, Bechara EJ, Vercesi AE. Permeabilization of the inner mitochondrial membrane by $\mathrm{Ca}^{2+}$ ions is stimulated by $t$-butyl hydroperoxide and mediated by reactive oxygen species generated by mitochondria. Free Radic Biol Med 1995; 18: 479-86.

25 Babior BM, Lambeth JD, Nauseef W. The neutrophil NADPH oxidase. Arch Biochem Biophys 2002; 397: 342-4.

26 Kim-Park WK, Moore MA, Hakki ZW, Kowolik MJ. Activation of the neutrophil respiratory burst requires both intracellular and extracellular calcium. Phagocytes 1997; 832: 394-404.

27 Wilsson A, Lundqvist H, Gustafsson M, Stendahl O. Killing of phagocytosed Staphylococcus aureus by human neutrophils requires intracellular free calcium. J Leukoc Biol 1996; 59: 902-7.

28 Banfi B, Molnar G, Maturana A, Steger K, Hegedus B, Demaurex $\mathrm{N}$, et al. $\mathrm{A} \mathrm{Ca}(2+)$-activated NADPH oxidase in testis, spleen, and lymph nodes. J Biol Chem 2001; 276: 37594-601.

29 Banfi B, Tirone F, Durussel I, Knisz J, Moskwa P, Molnar GZ, et al. Mechanism of $\mathrm{Ca}^{2+}$ activation of the NADPH oxidase 5 (NOX5). J Biol Chem 2004; 279: 18583-91.

30 Hammarberg T, Provost P, Persson B, Radmark O. The Nterminal domain of 0 binds calcium and mediates calcium stimu- 
lation of enzyme activity. J Biol Chem 2000; 275: 38787-93.

31 Farghali H, Masek K. Immunopharmacologic agents in the amelioration of hepatic injuries. Int J Immunopharmacol 1998; 20: 125-39.

32 Yang T, Poovaiah BW. Hydrogen peroxide homeostasis: activation of plant catalase by calcium/calmodulin. Proc Natl Acad Sci USA 2002; 99: 4097-102.

33 Kourie JI. Interaction of reactive oxygen species with ion transport mechanisms. Am J Physiol 1998; 275: C1-24.

34 Chiamvimonvat N, O’Rourke B, Kamp TJ, Kallen RG, Hofmann $\mathrm{F}$, Flockerzi $\mathrm{V}$, et al. Functional consequences of sulfhydryl modification in the pore-forming subunits of cardiovascular $\mathrm{Ca}^{2+}$ and $\mathrm{Na}^{+}$channels. Circ Res 1995; 76: 325-34.

35 Krippeit-Drews P, Britsch S, Lang F, Drews G. Effects of SHgroup reagents on $\mathrm{Ca}^{2+}$ and $\mathrm{K}^{+}$channel currents of pancreatic Bcells. Biochem Biophys Res Commun 1994; 200: 860-6.

36 Pei ZM, Murata Y, Benning G, Thomine S, Klusener B, Allen GJ, et al. Calcium channels activated by hydrogen peroxide mediate abscisic acid signalling in guard cells. Nature 2000; 406: 731-4.

37 Hidalgo C, Bull R, Behrens MI, Donoso P. Redox regulation of RyR-mediated $\mathrm{Ca}^{2+}$ release in muscle and neurons. Biol Res 2004; 37: 539-52.

$38 \mathrm{Xu} \mathrm{L}, \mathrm{Eu}$ JP, Meissner G, Stamler JS. Activation of the cardiac calcium release channel (ryanodine receptor) by poly- $S$-nitrosylation. Science 1998; 279: 234-7.

39 Meissner G. Regulation of mammalian ryanodine receptors. Front Biosci 2002; 7: D2072-80.

40 Oba T, Kurono C, Nakajima R, Takaishi T, Ishida K, Fuller GA, et al. $\mathrm{H}_{2} \mathrm{O}_{2}$ activates ryanodine receptor but has little effect on recovery of releasable $\mathrm{Ca}^{2+}$ content after fatigue. J Appl Physiol 2002; 93: 1999-2008.

41 Favero T, Zable AC, Abramson JJ. Hydrogen peroxide stimulates the $\mathrm{Ca}^{2+}$ release channel from skeletal muscle sarcoplasmic reticulum. J Biol Chem 1995; 270: 25557-63.

42 Suzuki YJ, Cleemann L, Abernethy DR, Morad M. Glutathione is a cofactor for $\mathrm{H}_{2} \mathrm{O}_{2}$-mediated stimulation of $\mathrm{Ca}^{2+}$-induced $\mathrm{Ca}^{2+}$ release in cardiac myocytes. Free Radic Biol Med 1998; 24: 318-25.

43 Suzuki YJ, Ford GD. Superoxide stimulates $\mathrm{IP}_{3}$-induced $\mathrm{Ca}^{2+}$ release from vascular smooth muscle sarcoplasmic reticulum. Am J Physiol 1992; 262: H1 14-6.

44 Missiaen L, Taylor CW, Berridge MJ. Spontaneous calcium release from inositol trisphosphate-sensitive calcium stores. $\mathrm{Na}$ ture 1991; 352: 241-4.

$45 \mathrm{Hu}$ QH, Zheng GM, Zweier JL, Deshpande S, Irani K, Ziegelstein RC. NADPH oxidase activation increases the sensitivity of intracellular $\mathrm{Ca}^{2+}$ stores to inositol 1,4,5-trisphosphate in human endothelial cells. J Biol Chem 2000; 275: 15749-57.

46 Kaneko M, Beamish RE, Dhalla NS. Depression of heart sarcolemmal $\mathrm{Ca}^{2+}$-pump activity by oxygen free radicals. Am J Physiol 1989; 256: H368-74.

47 Goldhaber JI. Free radicals enhance $\mathrm{Na}^{+} / \mathrm{Ca}^{2+}$ exchange in ventricular myocytes. Am J Physiol Heart Circ Physiol 1996; 40: H823-33.

48 Kato M, Kako KJ. $\mathrm{Na}^{+} / \mathrm{Ca}^{2+}$ exchange of isolated sarcolemmal membrane: effects of insulin, oxidants and insulin deficiency. Mol Cell Biochem 1988; 83: 15-25.

49 Shi ZQ, Davison AJ, Tibbits GF. Effects of active oxygen generated by DTT/ $/ \mathrm{Fe}^{2+}$ on cardiac $\mathrm{Na}^{+} / \mathrm{Ca}^{2+}$ exchange and membrane permeability to $\mathrm{Ca}^{2+}$. J Mol Cell Cardiol 1989; 21: 1009-16.

50 Coetzee WA, Ichikawa H, Hearse DJ. Oxidant stress inhibits NaCa-exchange current in cardiac myocytes: mediation by sulfhydryl groups? Am J Physiol 1994; 266: H909-19.

51 Rizzuto R, Bernardi P, Pozzan T. Mitochondria as all-round players of the calcium game. J Physiol 2000; 529: 37-47

52 Tornquist K, Vainio PJ, Bjorklund S, Titievsky A, Dugue B, Tuominen RK. Hydrogen peroxide attenuates store-operated calcium entry and enhances calcium extrusion in thyroid FRTL5 cells. Biochem J 2000; 351: 47-56.

53 Barlow RS, El-Mowafy AM, White RE. H(2)O(2) opens BK(Ca) channels via the PLA(2)-arachidonic acid signaling cascade in coronary artery smooth muscle. Am J Physiol Heart Circ Physiol 2000; 279: H475-83.

54 Doan TN, Gentry DL, Taylor AA, Elliott SJ. Hydrogen peroxide activates agonist-sensitive $\mathrm{Ca}(2+)$-flux pathways in canine venous endothelial cells. Biochem J 1994; 297: 209-15.

55 Suzuki YJ, Forman HJ, Sevanian A. Oxidants as stimulators of signal transduction. Free Radic Biol Med 1997; 22: 269-85.

56 Dreher D, Junod AF. Role of oxygen free radicals in cancer development. Eur J Cancer 1996; 32A: 30-8.

57 Kumasaka S, Shoji H, Okabe E. Novel mechanisms involved in superoxide anion radical-triggered $\mathrm{Ca}^{2+}$ release from cardiac sarcoplasmic reticulum linked to cyclic ADP-ribose stimulation. Antioxid Redox Signal 1999; 1: 55-69.

58 Gen W, Tani M, Takeshita J, Ebihara Y, Tamaki K. Mechanisms of $\mathrm{Ca}^{2+}$ overload induced by extracellular $\mathrm{H}_{2} \mathrm{O}_{2}$ in quiescent isolated rat cardiomyocytes. Basic Res Cardiol 2001; 96: 623-9.

59 Aley PK, Porter KE, Boyle JP, Kemp PJ, Peers C. Hypoxic modulation of $\mathrm{Ca}^{2+}$ signaling in human venous endothelial cells. Multiple roles for reactive oxygen species. J Biol Chem 2005; 280: 13349-54.

60 Andrade FH, Reid MB, Allen DG, Westerblad H. Effect of hydrogen peroxide and dithiothreitol on contractile function of single skeletal muscle fibres from the mouse. J Physiol 1998; 509: 565-75.

61 Cheng H, Lederer WJ, Cannell MB. Calcium sparks: the elementary events underlying excitation-contraction coupling in heart muscle. Science 1993; 262: 740-4

62 Zima AV, Copello JA, Blatter LA. Effects of cytosolic NADH/ $\mathrm{NAD}^{+}$levels on sarcoplasmic reticulum $\mathrm{Ca}^{2+}$ release in permeabilized rat ventricular myocytes. J Physiol 2004; 555: 727-41.

63 Xi Q, Cheranov SY, Jaggar JH. Mitochondria-derived reactive oxygen species dilate cerebral arteries by activating $\mathrm{Ca}^{2+}$ sparks. Circ Res 2005; 97: 354-62.

64 Isaeva EV, Shkryl VM, Shirokova N. Mitochondrial redox state and $\mathrm{Ca}^{2+}$ sparks in permeabilized mammalian skeletal muscle. J Physiol 2005; 565: 855-72. 